\title{
Bagasse: A Potential Organic Soil Amendment Used in Sugarcane Production'
}

\author{
Jehangir H. Bhadha, Nan Xu, Raju Khatiwada, Stewart Swanson, and Chris LaBorde ${ }^{2}$
}

\section{Introduction}

Bagasse is an agricultural by-product derived from the sugarcane milling process. It is a dry and fibrous residue left after the extraction of sugar juice from sugarcane. Approximately $300 \mathrm{lb}$ of bagasse are produced for every ton of sugarcane processed (Melati 2017). In general, bagasse composition consists of approximately $47 \%-52 \%$ cellulose, $25 \%-28 \%$ hemicellulose, and 20\%-21\% lignin (Dotaniya et al. 2016). When piled up and exposed to atmospheric conditions, it usually biodegrades within 60-90 days. Decomposition rate depends on factors such as temperature, moisture, and diversity and population of microorganisms present in the soil. Over 16 million metric tons $(\mathrm{mt})$ of sugarcane were produced in south Florida during the 2017-2018 harvest season, which would mean that over 2.5 million $\mathrm{mt}$ of bagasse were used as fuel to run the cogeneration units this past season (production values supplied by USSC, Sugarcane Growers Coop, and Florida Crystals) (Figure 1). Bagasse represents a waste by-product in need of disposal. Although bagasse is being used as a fuel source for the mill and some is being locally converted into paper plates and bowls (https://www.tellusproducts.com/), a lot of waste bagasse still remains. This article is a preliminary investigation into possible positive and/or negative effects of simply using bagasse as a soil amendment, especially when hauling, spreading, and incorporating bagasse comes with a cost irrespective of its effect on crop growth and yield. Developing recommendations regarding application amounts in the sugarcane production cycle within the EAA has not yet been attempted. As part of this preliminary study, we used four rates to assess the effect of bagasse on soil properties and sugarcane yield response: 2 -inch ( 85 ton/ha); 4-inch (170 ton/ha); 4-inch plus $58 \mathrm{~kg} /$ ha nitrogen; and a grower's control that did not receive any bagasse.

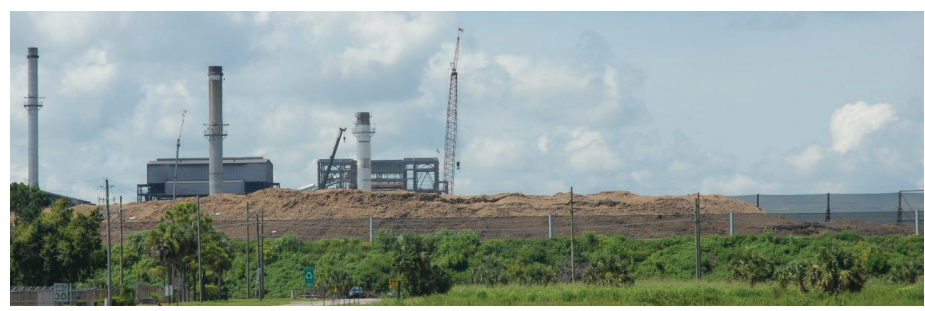

Figure 1. Pile of bagasse collected at the US Sugar processing plant in Clewiston, FL.

Credits: Stewart Swanson, UF/IFAS

Currently, bagasse is being utilized as fuel in the boilers of sugar factories to generate electricity and steam in the sugar industry (Nisrane 2017). Compared to conventional fossil fuels, bagasse is a more environmentally sound option because it is considered carbon-neutral. The amount of carbon released during incineration is equivalent to the amount of carbon assimilated in plant tissue during growth (Mann 2016). Bagasse is also a viable source of lignocellulosic biomass for clean-energy ethanol production with

1. This document is SL477, one of a series of the Department of Soil and Water Sciences, UF/IFAS Extension. Original publication date August 2020. Visit the EDIS website at https://edis.ifas.ufl.edu for the currently supported version of this publication.

2. Jehangir H. Bhadha, assistant professor, Department of Soil and Water Sciences, UF/IFAS Everglades Research and Education Center; Nan Xu, graduate student, Department of Soil and Water Sciences; Raju Khatiwada, chemist III, UF/IFAS EREC; Stewart Swanson, regional sugarcane Extension agent III, UF/IFAS Extension Hendry County; and Chris LaBorde, director, Ag Research and Development, United States Sugar Corporation; UF/IFAS Extension, Gainesville, FL 32611.

The Institute of Food and Agricultural Sciences (IFAS) is an Equal Opportunity Institution authorized to provide research, educational information and other services

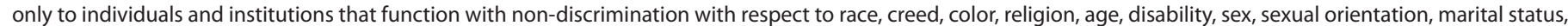

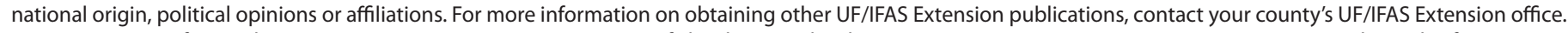
U.S. Department of Agriculture, UF/IFAS Extension Service, University of Florida, IFAS, Florida A \& M University Cooperative Extension Program, and Boards of County Commissioners Cooperating. Nick T. Place, dean for UF/IFAS Extension. 
a reduced greenhouse gas footprint. Bagasse is also being considered as an alternative to wood in the production of paper and paper products. While there are several options for utilizing bagasse, current disposal options cannot utilize the large tonnage that is produced annually. This fact sheet explores bagasse as a low-cost soil amendment for sustainable agricultural production systems (Figure 2).

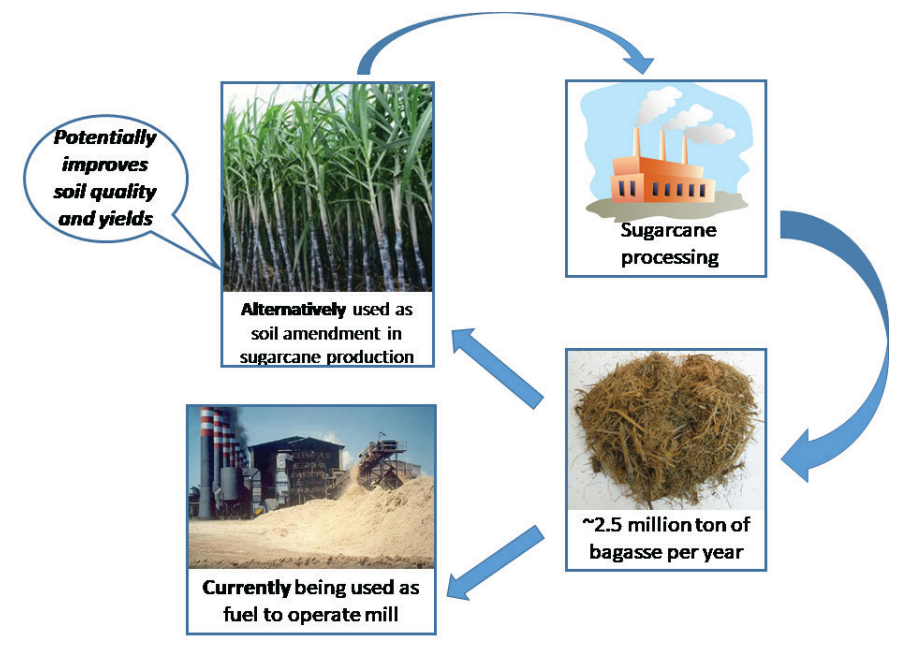

Figure 2. Sustainably closing the farming loop by utilizing bagasse as a potential soil amendment, possibly improving soil quality and increasing sugarcane yield.

Credits: Jehangir Bhadha, UF/IFAS

\section{Agronomic Benefits of Bagasse}

Bagasse has the potential to enhance soil quality, increase crop yields, and improve environmental quality. Application of bagasse on mineral soils can alter soil physicochemical properties. For example, bulk density (BD) and $\mathrm{pH}$ can be lowered due to bagasse's inherently low BD $\left(0.10 \mathrm{~g} / \mathrm{cm}^{3}\right)$ and $\mathrm{pH}(4.0 \pm 0.1)$ (Figure 3$)$. The ability to lower soil $\mathrm{pH}$ is uniquely important to growers in south Florida because of the calcium carbonate associated with the underlying bedrock. This may not universally be the case because native soils in Florida are typically acidic, and increased soil $\mathrm{pH}$ is often associated with management practices such as irrigation, soil fertility, etc. Bagasse can also improve soil water-holding capacity, organic matter (OM) content, and nutrient concentration of elements, such as potassium $(\mathrm{K})$, nitrogen $(\mathrm{N})$, and phosphorus $(\mathrm{P})$, that are essential for plant growth when applied on depleted soils. Due to its high OM content (95\%), bagasse has a high water-holding capacity (WHC) $(50 \pm 4.7 \%)$. The high OM content implies that the material could also mineralize quickly and benefits would be short-lived. In terms of WHC, sandy soils of Florida have larger pores than finer-textured soils, making it more difficult to hold soil water against gravity; consequently, sandy soils have a lower capacity to store soil water for plant uptake (Bhadha et al. 2017). Bagasse also has high nutrient content that is beneficial for plant growth. For example, bagasse can contain up to $263 \mathrm{mg} / \mathrm{kg}$ P, $997 \mathrm{mg} / \mathrm{kg}$ $\mathrm{K}$, and up to $2.7 \% \mathrm{~N}$ (Figure 3 ). In terms of P-use efficiency associated with calcareous soils, mineralization of bagasse could produce organic acids that can mobilize the insoluble $\mathrm{P}$ from soil to soil solution. Bagasse has also been found as the best substrate to support growth of cellulolytic and ligninolytic microorganisms (Poonam and Prabhu 1986). Bagasse application has the potential to offset fertilizer application. It can be used in combination with inorganic chemical fertilizers (Dotaniya et al. 2016).

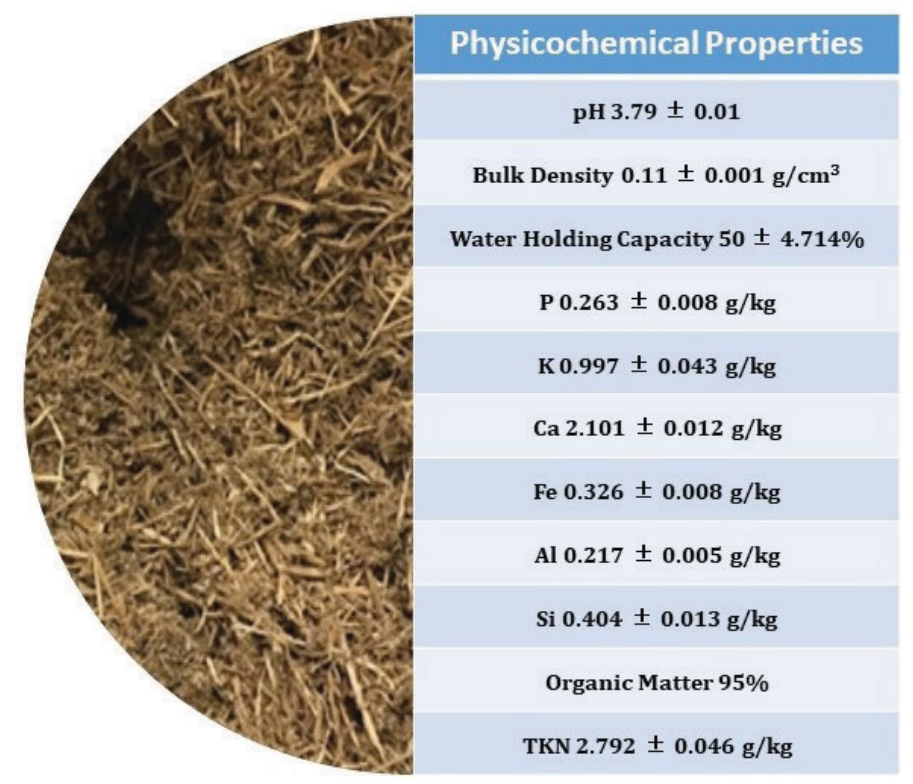

Figure 3. Physicochemical properties of bagasse $(n=6)$.

Credits: Nan Xu and Jehangir Bhadha, UF/IFAS

Sugarcane bagasse contains a high C:N ratio (Nisrane 2017; Torkashvand et al. 2008). This could initially immobilize some of the $\mathrm{N}$ from the soil, and potentially release nitrate later when mineralization sets in (Dotaniya 2016). Singh and Aulakh (2001) reported that the immobilization caused by the incorporation of high $\mathrm{C}: \mathrm{N}$ ratio crop residue could be balanced by application of inorganic fertilizer N. Nitrogen mineralization rate depends upon the composition of organic material (i.e., C:N ratio <20), soil type, and other environmental factors such as soil $\mathrm{pH}$ and temperature.

\section{Effect of Bagasse on Soil Microbiology}

Biotic and abiotic factors, including the soil $\mathrm{pH}$, plant species, soil carbon (C) and N, and management, strongly influence the diversity and composition of soil microbial communities. The availability of soil $\mathrm{C}$ and $\mathrm{N}$ is critical for soil microbes, just as it is for plants, and the concentrations and form of $\mathrm{C}$ and $\mathrm{N}$ in the soil can influence not only the abundance of soil microbes, but also the diversity. Bacteria 
and fungi are both influenced by soil organic matter. When bagasse is added to the soil, organic material acts as a food source for soil biota and generates organic enzymes after decomposition (Sharma et al. 2014). The addition of organic residue increases the soil organic carbon content, which accelerates soil microbial activities (Dotaniya et al. 2013). A study conducted at Gunung Madu Plantation in Indonesia showed that bagasse mulch increased litter fungal biomass and communities in the soil (Miura et al. 2013). This was a field study conducted at a sugarcane plantation in Sumatra, Indonesia, from September 2010 to January 2011. Thus, the duration of the study was approximately 5 months. The treatment used in this study was approximately 80 tons (wet weight) per hectare of bagasse mulch spread on the soil surface. In another study, bagasse mulch with no tillage had the highest microbial biomass and diversity compared to treatments such as no-tillage without bagasse mulch, and conventional tillage with and without bagasse mulch (Silvia 2014). This was a field study conducted over a year from June 2010 to July 2011, where approximately 80 tons (wet weight) per hectare of bagasse mulch were spread on the soil surface.

\section{Soil Health Benefits of Using Bagasse as an Amendment}

In fall 2017, a field study was conducted to test the feasibility of using bagasse as a soil amendment on a sandy soil. The main objective was to evaluate the effect of land application of bagasse on soil health indicators such as soil $\mathrm{pH}, \mathrm{BD}$, WHC, OM, macro- and micronutrients, tiller count, and ultimately yield when applied as a soil amendment to grow sugarcane (Figure 4). Bagasse was applied at four rates: no bagasse control; 2-inch (corresponding to approximately 85 tons per hectare, wet weight); 4 -inch (corresponding to approximately 170 tons per hectare, wet weight); and 4-inch with extra N (corresponding to $185 \mathrm{~kg}$ per hectare ammonium nitrate, or about $58 \mathrm{~kg} \mathrm{~N}$ per hectare). The extra application of $\mathrm{N}$ to 4 -inch bagasse was done to account for the initial immobilization of $\mathrm{N}$ that could occur. Detailed information about the methods used to measure soil health indicators can be found in Bhadha et al. (2017).
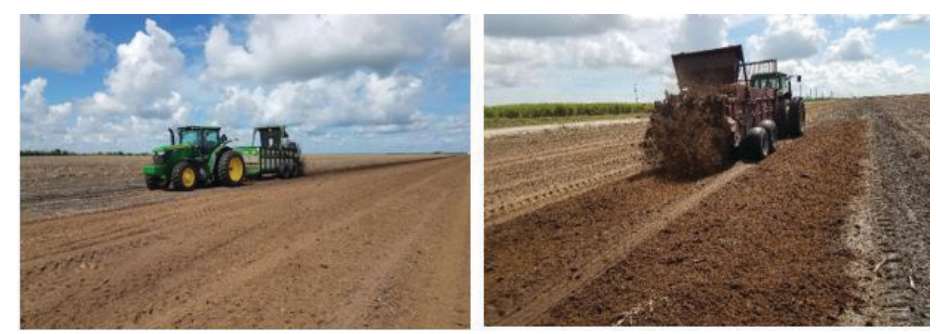

Figure 4. Bagasse being applied on sandy soil to evaluate its effect on soil health parameters.

Credits: Stewart Swanson, UF/IFAS
Figures 5 and 6 summarize changes in soil health properties after a single application of bagasse on mineral (sandy) soil. Results indicated that there was no significant difference in soil $\mathrm{pH}$ between times $\mathrm{t}_{0}, \mathrm{t}_{1}$ (150 days after application), and $\mathrm{t}_{2}$ (270 days after bagasse application). There was a significant reduction in soil bulk density when 4 -inch bagasse and 4-inch bagasse with extra $\mathrm{N}$ were applied to the soil at $t_{1}$. There was significant increase in water-holding capacity when 4 -inch bagasse and 4-inch bagasse with extra $\mathrm{N}$ were applied to the soil at $\mathrm{t}_{1}$ Soil $\mathrm{OM}$ also increased significantly when 4 -inch bagasse and 4-inch bagasse with extra $\mathrm{N}$ were applied to the soil. Both 2-inch bagasse and 4-inch bagasse treatments showed a significant increase in TKN at $\mathrm{t}_{1 .}$ A significant increase in Mehlich-3 $\mathrm{P}$ concentration was observed in all four treatments at $\mathrm{t}_{1}$; however, even at $\mathrm{t}_{2,}$ 2-inch bagasse, 4-inch bagasse, and 4-inch bagasse with extra $\mathrm{N}$ showed significantly higher $\mathrm{P}$ content. There was a significant reduction in Mehlich-3 K concentration in the 2 -inch bagasse treatment at $t_{1}$, but a significant increase was observed in 2-inch bagasse and 4-inch bagasse with extra $\mathrm{N}$ at $\mathrm{t}_{2}$.
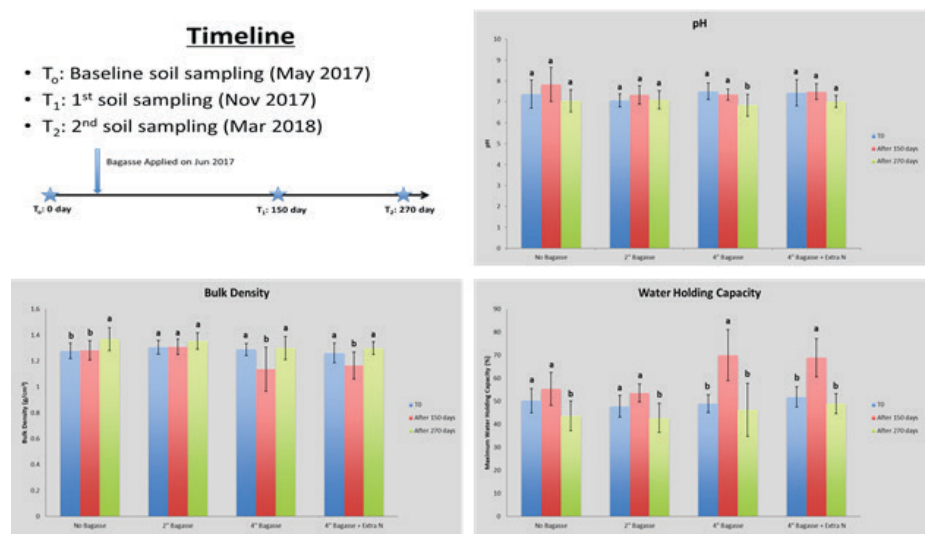

Figure 5. Timeline for bagasse study, and changes in soil health indicators ( $\mathrm{pH}$, bulk density, and water-holding capacity) over time. Error bars correspond to standard deviation. Different letters correspond to significant differences $(p<0.05)$.

Credits: Nan Xu and Jehangir Bhadha, UF/IFAS

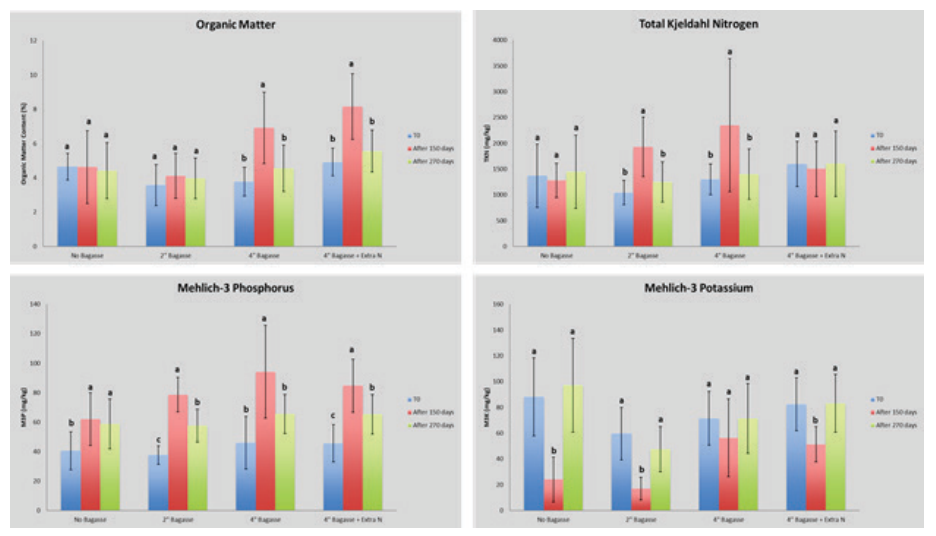

Figure 6. Changes in soil health indicators (organic matter, Total Kjeldahl Nitrogen, Mehlich-3 Phosphorus, and Melich-3 Potassium) over time. Error bars correspond to standard deviation. Different letters correspond to significant differences $(p<0.05)$.

Credits: Nan Xu and Jehangir Bhadha, UF/IFAS 
Compared to the control that received no bagasse amendment, treatments that received 2 -inch bagasse and 4 -inch bagasse with extra $\mathrm{N}$ both had almost twice as much tiller count and sugarcane yield, respectively (Figure 7). While sugarcane yields averaged $8,683 \mathrm{lb} / \mathrm{ac}$ for the control, there was nearly a $9 \%$ increase in yield with 2 -inch bagasse $(9,441$ $\mathrm{lb} / \mathrm{ac})$ and 4 -inch bagasse with extra $\mathrm{N}(9,369 \mathrm{lb} / \mathrm{ac})$. The application of bagasse increases tiller counts compared to the no-bagasse control treatment. However, the lower tiller counts and sugar yield observed in a 4-inch application of bagasse may be due to the higher C:N ratio that may have limited the amount of $\mathrm{N}$ available to the plant.

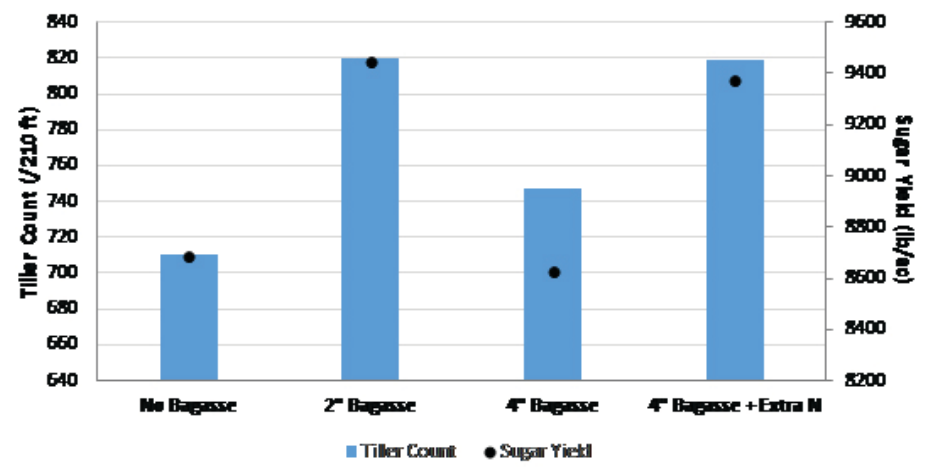

Figure 7. Comparing tiller count and sugarcane yields among bagasse amendment treatments.

Credits: Nan Xu and Jehangir Bhadha, UF/IFAS

\section{Conclusion}

Bagasse appears to be a good sustainable organic soil amendment that can be applied on mineral soils locally where it is being generated. A 2-inch application of bagasse and a 4 -inch application of bagasse with extra $\mathrm{N}$ showed significant yield response in sugarcane. In addition, numerous agronomic benefits of bagasse application include low $\mathrm{pH}$, low bulk density, high water-holding capacity, and high organic matter content. Nutrient composition of bagasse is typically high, yet it can be variable. As an amendment, bagasse could supplement sandy soils with major and micronutrients. Due to the high organic matter content and the high C:N ratio, some of the $\mathrm{N}$ and $\mathrm{P}$ fertilizer applied during crop production can potentially become immobilized. Ultimately, the timing and rate of bagasse application would depend on the soil and crop types. Currently, there are no recommendations in place for sugarcane growers on utilizing bagasse on mineral (sandy) soils. This would be a good starting point if they want to sustainably incorporate their bagasse stockpiles back into the sugarcane production cycle.

\section{References}

Bhadha, J.H., J. Capasso, R. Khatiwada, S. Swanson, and C. LaBorde. 2017. Raising Soil Organic Matter Content to Improve Water Holding Capacity. SL447. Gainesville: University of Florida Institute of Food and Agricultural Sciences. https://edis.ifas.ufl.edu/ss661

Bhadha, J. H., J. Capasso, R. Schindelbeck, and A. Bacon. 2017. Tools for Evaluating Soil Health. SL443. Gainesville: University of Florida Institute of Food and Agricultural Sciences. https://edis.ifas.ufl.edu/ss657

Dotaniya, M. L., S. C. Datta, D. R. Biswas, C. K. Dotaniya, B. L. Meena, S. Rajendiran, K. L. Regar, and M. Lata. 2016. "Use of Sugarcane Industrial By-products for Improving Sugarcane Productivity and Soil Health." International Journal of Recycling of Organic Waste in Agriculture 5: 185-194.

Dotaniya, M. L., M. M. Sharma, K. Kumar, and P. P. Singh. 2013. "Impact of Crop Residue Management on Nutrient Balance in Rice-Wheat Cropping System in an Aquic Hapludoll." J. Rural Agric. Res. 13: 122-123.

Mann, A. P. 2016. "Chapter 9: Cogeneration of Sugarcane Bagasse for Renewable Energy Production." In SugarcaneBased Biofuels and Bioproducts, edited by O'Hara and Mundree. John Wiley \& Sons, Inc.

Melati, R. B., A. A. Schmatz, F. C. Pagnocca, J. Contiero, and M. Brienzo. 2017. "Sugarcane Bagasse: Production, Composition, Properties, and Feedstock Potential." Chapter 1. https://www.researchgate.net/publication/317770155_ Sugarcane_bagasse_Production_composition_properties_and_feedstock_potential

Miura, T., A. Niswati, I. G. Swibawa, S. Haryani, H. Gunito, and N. Kaneko. 2013. "No Tillage and Bagasse Mulching Alter Fungal Biomass and Community Structure during Decomposition of Sugarcane Leaf Litter in Lampung Province, Sumatra, Indonesia." Soil Biology and Biochemistry 58: 27-35.

Nigam, P., and K. A. Prabhu. 1986. "The Effects of Some Added Carbohydrates on Cellulases and Ligninase and Decomposition of Whole Bagasse." Agricultural Wastes 17: 293-299.

Nisrane, N. 2017. Effects of Filter Cake and Bagasse on Selected Soil Properties and Response of Rice (Oryza sativa L.) to Their Application on Calcareous Sodic Soils at Amibara, Ethiopia. Dissertation. Ethiopia: Haramaya University. 
Sharma, M. M., Y. K. Sharma, M. L. Dotaniya, and P.

Kumar. 2014. "Effect of Different Levels of FYM, Press Mud and Zinc Sulphate Application on Soil Properties." J. Plant Develop. Sci. 6: 455-459.

Silvia, S., T. Miura, K. Nobuhiro, K. Fujie, U. Hasanuddin, A. Niswati, and S. Haryani. 2014. "Soil Microbial Biomass and Diversity Amended with Bagasse Mulch in Tillage and No-tillage Practices in the Sugarcane Plantation." Procedia Environmental Sciences 20: 410-417.

Singh, K., and M. S. Aulakh. 2001. "Nitrogen Immobilization-Mineralization in a Sandy Loam Soil (Typic Ustochrept) Amended with Crop Residues at Varying Moisture Regimes." Journal of the Indian Society of Soil Science 49: 198-202.

Torkashvand, A., A. Mohammadi, S. Radmehr, and H. Nadian. 2008. "Investigation of Compost Production from Cane Organic Wastes with the Different Treatment of Urea and $\mathrm{pH}$ by Using Trichoderma Fungi." Biotechnology 7:

739-744. 